\title{
Correlation of Sentul Chicken Body Weight at DOC age of 1,2 and 3 Months
}

\author{
L. H. M. Gultom, Gushairiyanto, and Depison* \\ Animal Science Study Program, Faculty of Animal Science, Universitas Jambi, \\ Jl. Jambi-Ma. Bulian KM 15 Mendalo Darat Jambi 36361 Indonesia \\ * Corresponding Author: depison.nasution@unja.ac.id
}

\begin{abstract}
The purpose of this study was to determine the correlation between body weight and body weight gain of Sentul chickens aged DOC, 1, 2 and 3 months. The research materials were Sentul and Merawang chicken. This research method was an experimental method with a sample of 41 males and 41 females from each breed. The data collected includes; body weight and body weight gain of DOC-3 months old. The data collected were analyzed using the ttest of average differences (t-test), the relationship between body weights was analyzed using the correlation test. Based on the results and discussion, it concluded that the body weights of male and female of Sentul chicken aged DOC-2 months were not significantly different $(\mathrm{P}>0.05)$, but significantly different $(\mathrm{P}<0.05)$ at the age of 3 months. The highest body weight gain was at 1-2 months in both males and females. The highest correlation between body weights for a certain age is between 1-2 months so that 1-month body weight is a good bodyweight for selection based on body weight.
\end{abstract}

Key words: body weight, Sentul chicken, correlation

\section{INTRODUCTION}

Indonesia is a tropical country that has abundant germplasm diversity. One of the germplasm owned is the diversity of livestock including local chicken, which have the potential to be developed as a fulfilment of animal protein for the Indonesian people. Indonesia has 32 types of local chicken (ecotypes) consisting of several clumps with different morphological characteristics and unique to their area of origin and each type has its advantages (Nuraini et al., 2016). Indonesian local chicken has the potential as a producer of meat and eggs. Local chicken breeding can be done by increasing the quality of the breed produced (Ariyanti et al., 2017). One of the local chicken in Indonesia is Sentul chicken (Mariandayani et al., 2013).

Sentul chicken is a native local chicken from the Ciamis district which can be used as a producer of meat and eggs. Generally, Sentul Chicken that is kept traditionally are slaughtered at 12 weeks of age, while Sentul Chicken that is is kept intensively can be slaughtered at 8-10 weeks of age (Ermansyah et al., 2015). Sentul chicken body weight at the age of 20 weeks can reach 1.60 $\mathrm{kg}$ if maintained intensively (Nataamijaya, 2010). Local chicken that is kept generally have high diversity, productivity and genetic quality are lower than purebred chicken, so it is necessary to make a selection as an effort to increase productivity and genetic quality of livestock. The selection process can be done by collecting basic data in bodyweight, body weight gain, and correlations between body weights for a certain age.

Bodyweight is one indicator of livestock productivity that has economic value. Bodyweight is also one of the controls in growth and weighing. Growth is usually expressed by measuring the increase in body weight repeatedly expressed by daily weight gain. Bodyweight gain is the increase in body weight achieved by an animal during a certain period, generally, bodyweight gain will increase at the beginning of growth, and will decrease again when the animal reaches body maturity. The relationship between body weights at a certain age is an important indicator in the selection effort, whereby looking at the highest correlation or correlation between body weights it can be determined the best time to make a selection based on body weight. Based on the description above, it is necessary to conduct research that can be used as a reference in selection efforts to increase the bodyweight of Sentul chicken in the future.

\section{MATERIALS AND METHODS}

The research material was Sentul and Merawang chicken which was reared from DOC until the age of 3 months. The tools used in this study were a scale with a capacity of $3 \mathrm{~kg}$ with a minimum scale of 0.1 grams, a camera, a 1 unit cage, a place to feed and drink, feed and drink, vaccinations, and medicines.

The method used in this study is an experimental method with a sample of 41 males 
and 41 females which were reared from DOC until the age of 3 months. The system of rearing chicken in the colony cage with continuous feeding and drinking (ad libitum). The size of the cage used is $4 \times 3 \times 1.8 \mathrm{~m}$ which is equipped with a feed, drinking place, and lamp for lighting. The data collected are bodyweight and bodyweight Gain. The data that has been collected is grouped by gender. Data on body weight and body weight gain were analyzed using the average difference test (t-test), and the relationship between body weights for certain ages using the Correlation test (Gasperz, 1992).

\section{RESULT AND DISCUSSION}

\section{Sentul Chicken Bodyweight of DOC-3 Months Age}

The body weights of male and female Sentul chicken aged DOC up to 3 months of age are presented in table 1 . Table 1 shows that the results of the different test results in the average body weight of male and female. Sentul chickens aged DOC-2 months were not significantly different $(\mathrm{P}>0.05)$. However, the average body weight of male and female Sentul chicken was significantly different $(\mathrm{P}<0.05)$ at the age of 3 months. Although the average difference test showed results that were not significantly difference between males and females, the overall bodyweight of male Sentul chicken was higher than that of female Sentul chicken. This is due to differences in growth hormones between males and females, male sex hormones result in faster growth in male cattle than female livestock.

The average body weight of male and female Sentul chicken from this study at the age of 1 month was lower, but at the age of 2 and 3 months, it was higher than the research by Kurnia (2011), the average body weight of Sentul chicken aged 4 weeks was $241.10 \pm 4.52$. g, body weights at age 8 in males and females were $367.7 \pm 12.05$ $\mathrm{g}$ and $331 \pm 46.85 \mathrm{~g}$, while the weight at 12 weeks of age in males and females were $532.1 \pm 84.78 \mathrm{~g}$ and $459.2 \pm 23,19 \mathrm{gr}$. The average body weight of male and female Sentul chicken aged 2 months was also higher than the results of the study of Meyliyana et al. (2013) the average body weight of Sentul Abu chicken aged 2 months male and female were $611.74 \pm 35.69 \mathrm{gr}$ and $614.35 \pm 26.06$ gr, respectively. The average body weight of Sentul chicken aged 2 and 3 months in this study was also higher than that of Sopian et al. (2015) the average body weight of Sentul chicken crossed with Pelung that were reared intensively at the age of 2 and 3 months was $267.5 \pm 46.3$ gr and 451.4 \pm 86.8 gr, it can be concluded that the rearing system of this study is quite good seen of body weight which is quite high compared to the results of other studies.

Table 1 . Body weight of Sentul DOC chicken at 3 months

\begin{tabular}{lcc}
\hline \multicolumn{1}{c}{ Chicken age } & Male $(\mathrm{g})$ & Female $(\mathrm{g})$ \\
\hline DOC & $33.85 \pm 2.83^{\mathrm{a}}$ & $33.58 \pm 2.51^{\mathrm{a}}$ \\
First month weight & $217.06 \pm 35.10^{\mathrm{a}}$ & $211.52 \pm 47.9^{\mathrm{a}}$ \\
Second month weight & $632.89 \pm 66.06^{\mathrm{a}}$ & $615.28 \pm 74.69^{\mathrm{a}}$ \\
Third month weight & $1021.44 \pm 68.95^{\mathrm{a}}$ & $956.86 \pm 81.63^{\mathrm{b}}$ \\
\hline
\end{tabular}

Note: Different superscript letters in the same line for each gender mean significant difference $(\mathrm{P}<0.05),( \pm$ :sd).

\section{Sentul Chicken Bodyweight Gain of DOC-3 Months Age}

Body weight gain of male and female Sentul chicken aged DOC-3 months is presented in Figure 1. Figure 1 shows body weight gain of male and female Sentul chicken from DOC-3 months of age. The increase in body weight of males aged DOC-1 mo, 1-2 mo, and 2-3 mo, respectively, were $6.11 \pm 1.1,13.86 \pm 1.45$, and $12.95 \pm 1.56 \mathrm{~g} / \mathrm{head} /$ day, while in females were $5.93 \pm 1.33, \quad 13.46 \pm 1.63$, and $11.39 \pm 1.71$ $\mathrm{g} / \mathrm{head} / \mathrm{day}$.

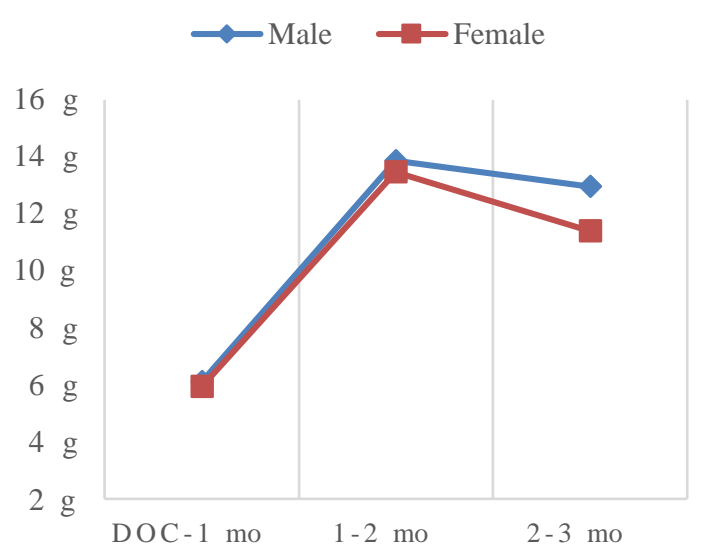

Figure 1. Body weight gain of Sentul chicken of DOC-3 months aged 
Bodyweight gain in males and females aged DOC-1 months and 1-2 months was not significantly different $(\mathrm{P}>0.05)$, but significantly different $(\mathrm{P}<0.05)$ at 2-3 months of age.

Bodyweight gain of male and female Sentul chicken tended to be low at the age of DOC-1 month and increased at the age of 1-2 months, but decreased again at the age of 2-3 months. This is presumably because at the age of 1-2 months is a phase of meat growth so that there is an increase in body weight gain in Sentul chicken. Accordance with Rahayuningtyas et al. (2014) that the bodyweight of poultry began to increase at the age of 14 days and increased at the age of 28 days and 35 days. This is a result of increasing levels of growth hormone at the age of 21 days and increasing at the age of 35 days. Generally, the period of growth acceleration occurs before the cattle experience puberty (sexual maturity) after which there is a slowdown (Agustina et al., 2013). Furthermore, based on the research results of Habiburahman et al. (2018) the body weight growth of IPB D-1 G4 chicken increased at 1-4 weeks of age, then decreased bodyweight growth in male IPB D-1 G4 chicken at 7 and 9 weeks of age and in females aged 5, 7, and 9 weeks. Decreased body weight growth at the age of 7 and 9 weeks. High body weight gain in the early stages of rearing is very profitable economically because rearing can be done in a short time, so to produce meat in a short time, Sentul chicken have the potential to be developed.

\section{Correlation between Sentul Chicken Body Weight at a Certain Age}

The correlation between body weights of Sentul chicken at a certain age in males and females is presented in Figure 2. Figure 2 shows the correlation between body weights of a certain age in males and females. Correlation coefficient (r) between body weights DOC-1 mo, DOC- 2 mo, DOC-3 mo, 1-2 mo, 1-3 mo, 2-3 mo in males, respectively $57.4 \%, 49.8 \%, 39.2 \%, 79.1 \%, 71.9 \%$ and $78.8 \%$, while in females respectively $54.3 \%$, $38.7,39.8 \%, 79.7 \%, 71.2 \%$ and $76 \%$. Overall, in both males and females, the highest correlation was between 1-2 months of age weight, then the correlation between 2-3 months and 1-3 months of weight was also quite high, while the correlation between DOC and certain body weights was quite low. This is in accordance with the opinion of Wulandari (2017), the difference in DOC weight between $41-55 \mathrm{~g}$ with a range of $14 \mathrm{~g}$ does not affect the performance of chicken production which includes body weight gain and final weight.

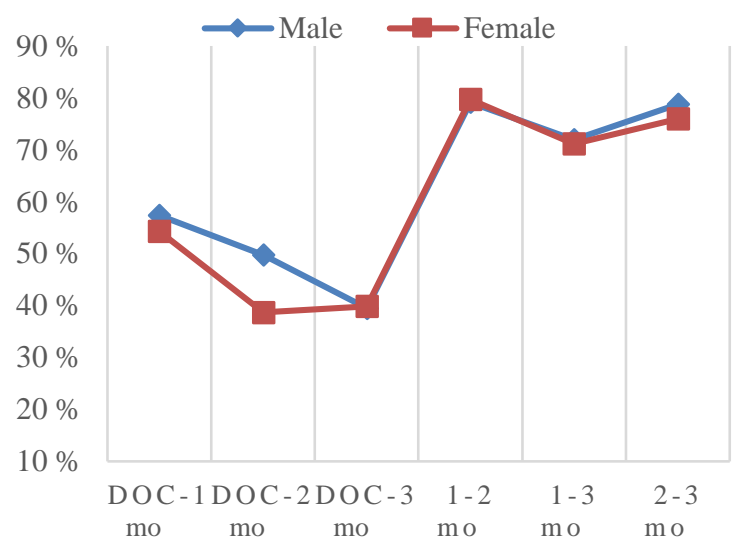

Figure 2. Correlation between body weights of Sentul chicken of a certain age

Based on the research results of Wardono et al. (2014) the correlation between DOC weight and ten weeks of weight showed a low or weak relationship, with a correlation value of $2 \%$ each.

The high value of the correlation coefficient in this study means that body weight at one month of age can affect body weight at 2 and 3 months, where the greater the body weight at 1 month, the greater the body weight at 2 and 3 months. That means that the weight of 1 month will affect the bodyweight of the next so that it can be used as the basis for the selection process of Sentul chicken. The value of the correlation coefficient is important in the selection to produce the desired production value.

\section{CONCLUSION}

The bodyweight of male Sentul chicken is generally higher than that of females, the highest body weight gain is at 1-2 months in both males and females. The highest correlation between body weight for a certain age is between 1-2 months so that 1-month body weight is a good bodyweight for selection based on body weight.

\section{REFERENCES}

Agustina, D., N. Iriyanti, dan S. Mugiyono. 2013. Pertumbuhan dan konsumsi pakan pada berbagai jenis itik lokal betina yang pakannya disuplementasi probiotik. Jurnal Ilmiah Peternakan 1 (2): 691-698.

Ariyanti, R., N. Ulupi, T. Suryati, dan R. I. Arifiantini. 2017. Performa produksi dan reproduksi ayam sentul dengan konsentrasi IgY berbeda dalam serum darah. Jurnal 
Ilmu Produksi dan Teknologi Hasil Peternakan 5 (3): 89-93.

Gaspersz, V. 1992. Teknik Analisis dalam Penelitian Percobaan. Volume II. Tarsito, Bandung.

Habiburahman, R., S. Darwati, dan C. Sumantri. 2018. Pola pertumbuhan ayam silangan pelung sentul kampung ras pedaging (IPB D-1) g4 umur 1-12 minggu. Jurnal Ilmu Produksi dan Teknologi Hasil Peternakan 6 (3): 81-89.

Kurnia, Y. 2011. Morfometrik Ayam Sentul, Kampung dan Kedu pada Fase Pertumbuhan dari Umur 1-12 Minggu. Skripsi. Institut Pertanian Bogor, Bogor.

Mariandayani, H.N., D.D. Solihin, S. Sulandari, dan C. Sumantri. 2013. Keragaman fenotipik dan pendugaan jarak genetik pada ayam lokal dan ayam broiler menggunakan analisis morfologi. Jurnal Veteriner 14 (4): 475-484.

Meyliyana, S. Mugiyono, dan Roesdiyanto. 2013. Bobot badan berbagai jenis ayam Sentul di gabungan Kelompok Tani Ternak Ciung Wanara Kecamatan Ciamis Kabupaten Ciamis. Jurnal Ilmiah Peternakan 1 (3): 985-992.
Nataamijaya, A.G. 2013. Pengembangan potensi ayam lokal untuk menunjang peningkatan kesejahteraan petani. Jurnal Litbang Pertanian 29 (4): 131-138.

Nuraini, Z. Hidayat, dan Adrial. 2016. Produksi dan karakteristik telur ayam merawang dengan sistem pemeliharaan secara intensif di kebun percobaan Petaling Kepulauan Bangka Belitung. Prosiding Seminar Nasional Inovasi Teknologi Pertanian. Banjarbaru, pp. 1108-1114.

Sopian, Y., S. Darwati, dan C. Sumantri. 2015. Performa F1 antara ayam Sentul $\mathrm{x}$ Kampung dan ayam Pelung x Sentul pada umur 0-12 minggu. Jurnal Ilmu Produksi dan Teknologi Hasil Peternakan 3 (3): 131137.

Wardono, P. H., C. Sugihono, H. Kusnadi, dan Suprijon. 2014. Korelasi antara beberapa kriteria peubah produksi pada ayam Buras. Prosiding Seminar Nasional Inovasi Teknologi Pertanian Spesifik Lokasi. Banjarbaru, pp. 577-585.

Wulandari, M. 2017. Pengaruh Bobot DOC terhadap Performa Produksi Ayam Broiler Modern pada Sistem Kandang Litter. Skripsi. Universitas Andalas, Padang. 